\title{
GLOBAL EDUCATIONAL SPACE - SIMILARITIES AND DIFFERENCES
}

\author{
Bozo Nikolic, Jelena Dakic, Ljiljana Ruzic-Dimitrijevic, The Higher Education Technical Schools of \\ Professional Studies in Novi Sad, Serbia, ljdimitrijevic@gmail.com
}

\begin{abstract}
The paper presents new study rules in Serbia that are also accepted in most European countries. The rules are in line with the Bologna Declaration, and are designed to form a single European system of education. The paper discusses the challenges and attempts to compare European, Russian and American systems of higher education with the system in Serbia with the aim of increasing student and teacher mobility in Europe and beyond.
\end{abstract}

Keywords: higher education system, comparison, student and teacher mobility

\section{INTRODUCTION}

More than twenty years there has been being built a unique space in Europe in the field of higher education that could enable a horizontal and vertical mobility of students and teachers. Besides, the same mobility could be achieved in the field of life-long education and education of adults. Ministers of numerous European countries took part in signing of this document [4], and this organization does not represent a part of the formation of the European Union.

The occurrence of "Bologna" in the field of higher education in Serbia provoked different opinions and reactions. The public listened a lot about it, but right information did not reach sufficiently. The media and great number of teachers and management of higher education institutions showed a great deal of non-comprehension, which is not unusual because even nowadays they either do not know or want to know a lot about it. It seems that the "privilege" belongs only to those who immediately participated in the preparation of material for accreditation in higher education schools which understood the process as a part of their better future.

Although the majority of higher education institutions are accredited and new Law on education [22] also underwent some changes, many of them implicitly continued with their old system of work. The reasons for that are different. Besides, silent resistance of professors has also occurred because the Bologna Declaration asks for much greater engagement. It has also provoked a vociferous resistance of students, because the Bologna Declaration also implies much more and continual work. Unfortunately, the point is that students do not articulate adequately their claims. Instead of persistent demanding to be on the budget with 48 points and have greater number of examination terms, students should insist that professors strictly apply the Bologna Declaration, provide conditions that with regular work and fulfilling pre-term conditions the very exam becomes passable in the first examination term [14].

\section{WHICH ARE THE CHANGES THAT BOLOGNA MAKES}

During reforming, all the time the information about the application of the Bologna Declaration in immediate and distant surrounding was being gathered. It was particularly monitored the application of the Bologna Declaration in immediate surrounding, while at the same time there were many differences in the very approach [17], [18], [19].

As the deadline for the beginning of the Bologna Declaration implementation expired, it was expected that uncertainties and doubts on this implementation disappear, which unfortunately did not happen. Therefore, we conducted the analyses of studying rules in European countries, thus helping ourselves in clearing out many uncertainties [11].

Moreover, the analyses showed that the European space of higher education is more balanced than it used to be and that it is achieved by the very elements that the Bologna Declaration promotes. 


\section{Issues in Information Systems}

Volume 14, Issue x, pp. 451-457, 2013

Until the Bologna Declaration was introduced to Serbia, people were of the opinion that our education system is among the best in the world and that we are among the leading countries in the world according to the number of students and highly educated people. Scientific workers at the faculties were autonomous, untouchable and elusive to the students.

Studies were characterized by a long period of studying, low passing rate and great freedom of choice - the freedom for students relating to classes and their obligations at the faculty.

Rules were established that formed certain habits and system which had no similarities with elements that the Bologna Declaration introduced. Not even the mixture of these two systems was possible because it was impossible to function in that way. Roughly speaking, some of the old characteristics of the system of studying were the following:

- Independently of the quality, the studies were free for everyone.

- The classes were obligatory to attend only in theory, and students' activities were neither necessary nor assessed.

- The number of examination terms significantly differed from faculty to faculty, being frequently realized even in the street.

- The next school year could be enrolled with a number of unparsed exams which later never repeated. A repeated school year was lost and students used to spend it out of the faculty.

- There was also a category of advanced university students with great number of unparsed exams. Many of the students even were retired with this status.

These are only some of the inherited characteristics of the system and when we analyze the postulates of the Bologna Declaration it is clear that the difference is significant and essential. Objectives from the Bologna Declaration text:

„,...Adoption of a system of easily readable and comparable degrees...

Adoption of a system essentially based on two main cycles, undergraduate and graduate...

Establishment of a system of credits - such as in the ECTS system - as a proper means of promoting the most widespread student mobility. Credits could also be acquired in non-higher education contexts, including lifelong learning, provided they are recognised by receiving Universities concerned.

Promotion of mobility by overcoming obstacles to the effective exercise of free movement...

Promotion of European co-operation in quality assurance with a view to developing comparable criteria and methodologies.

Promotion of the necessary European dimensions in higher education, particularly with regards to curricular development, inter-institutional co-operation, mobility schemes and integrated programmes of study, training and research..." [4]

There are three main goals: international competitiveness, mobility and employability in the European Higher Education Area with common social and cultural heritage [13]. Considered from the point of view of its basic participants, teachers and students, the essence of the Bologna Declaration is the following:

- A teacher must evaluate the time and effort necessary for adopting material and elaborate the way of monitoring and assessment of students. Points attributed to subjects must be agreed on and represent necessary load for student for its realization. Teachers must pay significantly more attention to students in order to force and motivate them to fulfill all their obligations timely.

- Students must be far more active because only then will they be able to fulfill the set requirements of their subjects timely.

Rules of studies are adapted to these requirements and completely opposed to the old rules that could not provide the student with successful studying. Nevertheless, silent or vociferous resistance appeared because it was difficult to break from bad old habits. Those who represented the bearers of the Bologna process faced with all these problems. Naturally, since the beginning there were present difficulties and uncertainties that gradually diminished. Everything that was undertaken required a lot of effort for the analysis and constant check-up and control of its attitude validity [15]. 


\section{EXPERIENCE OF OTHERS}

Keeping track of such an idea also assumed following solutions and using experience of European countries in order to make clear what is common to rules of studying. We took an example of non-European area - Canada, where the Bologna Declaration is not being into power. Having in mind close cooperation with two universities from Russia and knowing their experience we also used it, although they do not represent a part of the Bologna space. What is interesting is the fact that in both mentioned non-European areas where the Bologna Declaration is not being applied the requirements are even stricter than those of the Declaration. However, they also represent the concern of this paper since being maximally interesting.

The data were taken from samples of many countries like: Norway, Poland, Bulgaria, Italy, France, England, Czech Republic, Russia and Canada. We tried to get clear answers to questions like:

- conditions of enrollment to the faculty

- whether the studies are according to the Bologna Declaration

- types of studies

- academic year and ECTS

- method of passing exams and examination terms

- enrollment of next year

- fees

- $\quad$ work and independence of teachers

Further in the paper there follows an attempt to briefly point at differences, namely the attempt to outline what is there in common. At that point, there occurred many problems about understanding different systems of education, where uncertainties and differences were noted also in the examples of school systems of primary and secondary education, as well as at the "exit" of studies after finishing the fourth or fifth year.

It was also noted that the approaches in state and privately-owned schools and faculties are different. So, for example, the author from Bulgaria [7] is a professor at an American college which could create difficulties to form a unique picture about studying in that country, because beside that college there also exist both private and state ones. Different systems can also be applied in Germany, France and England. Out of all, we come to the conclusion that standpoints in this paper should be looked upon conditionally, with caution. However, it is difficult to tell the exact story about studying in our country in which all of us would agree on its exactness.

\section{HOW TO BECOME A STUDENT AND CONDITIONS OF ENTRY}

This part will discuss the parallel of the conditions necessary for someone to enroll the faculty or higher education school and the ways to achieve that goal in different countries. Why is that of importance?

Higher Education Technical School of Professional Studies in Novi Sad has been maintaining cooperation with Sankt Petersburg University from Russia for years. The cooperation is developed in the field of protection, particularly from fire and rescuing in emergency situations. There are numerous and widely spread and intensive elements of this cooperation. Its final aim is the possibility of the formation of joint studies and programmes. But, we came to an insurmountable problem there - in Russia students enroll their studies two years earlier then students in our country, therefore it is extremely difficult to agree on plans and programmes.

We established similar cooperation with Macon State College from the USA in the field of IT where we came across some other problems in agreement on programmes.

Bulgaria System of pre-school, primary and secondary education is the same as ours and fully clear. One becomes a student after he passes final examination at the age of 19. There is also an entrance examination test, but some institutions apply their own rules of enrollment [7].

Italy In Italy one can become a student also at the age of 19. You have to pass final examination, and schooling lasts for 13 years within primary, lower grades of secondary and secondary school. There are certain differences in the system, depending on the faculty you want to enroll [6]. 
Great Britain In this field in different areas and universities within one country, there are numerous variants, possibilities and differences. Basically, it can be said that one enrolls the faculty after six years of elementary school and seven years of secondary school [16].

Norway There is quite classic and recognizable pattern. Thirteen years of school, out of which three years of secondary school, after which there follows the enrollment to the faculty at the age of 19 based on grades achieved from both school and entrance examination test [5].

Poland Higher education studies are enrolled after one year of pre-school, six years of elementary school, three years of post-elementary school and three years of secondary school. At the age of 19, after passing final examination, the enrollment of the desired studies is possible according to the number of points a student has achieved, particularly the points achieved on final examination [21].

France The differences are present only in lower secondary school, all the rest is recognizable. Usually marks from school and final examination are taken into account, but a lot depends on the type of studies, school and the prestige of the very institution [3].

Czech Republic In relation to most countries, pre-school education is longer. All the other elements fit into already existing matrix [2].

Russia Studies are enrolled after 11 years of obligatory elementary education that starts at the age of 6 , so that freshmen students are 17. Secondary school, which last for three years, is enrolled after elementary school mainly by students who have no plans of enrolling higher education institutions [12].

Canada In Canada, university is enrolled after four years of elementary school and 7 to 9 years of secondary schools, depending on the province. The enrollment is based on competition of candidates' school marks with prior definition of minimal entry points [20].

Generally, analyzing the enrollment and its methods, all the faculties and higher education schools have almost identical principles and in all the countries there are a lot of similarities. Almost all of the students are 19 when they enroll the faculty (except in Russia) and have to pass final examination, but there are also other ways of enrollment. Entry conditions are marks from final examination and sometimes points achieved on some entrance examination test. All the students attended school for 12 years which is differently defined and have 1 to 3 years of pre-school education.

\section{DO RULES OF STUDYING FOLLOW THE BOLOGNA PROCESS?}

The Bologna process relates to the countries from one part of European area, and there is also a very interesting part consisting of Canada, the USA and Russia. Those are countries with quality system of higher education, similar to the Bologna system, if not even more quality than it.

This question is not going to be answered according to the matrix as it is done in the previous question. Here, the answer could be very short and clear, either yes or no. There is also a transitional solution which is very difficult to be described.

In the majority of countries, the reforming of education system started in 1999 when most countries signed the Bologna Declaration, and later passed the law in accordance with it. According to that Declaration, all the institutions should be accredited by national accreditation bodies. Strong devotion to the Bologna guidelines is showed by Bulgaria, Italy, Norway, Poland and the Czech Republic. It could be said that Great Britain partially endeavours to satisfy the Bologna process, while France could be a few steps back, but nevertheless it still uses transfer points that are partially clear to us. 


\section{Types of studies}

This question presents itself as the most important one, and the answers are very short, clear and similar in all the countries. There are the systems of basic, master and doctoral studies, being the following: 3 years, $3+1$ years (specialized studies), $3+2$ years and $3+2+3$ years. The studies are mostly academic at all the levels and professional at the first and second (specialized) level. In some countries, there are some exceptions; longer studies in some programmes, master, as well as professional masters.

However, we again return to the example of Russia. If students enroll studies two years earlier and if they study for five years, with some subjects in their programmes that are present in Serbian secondary schools, it is very difficult to compare those programmes. In Russia, they also started to apply some system similar to the Bologna one, but with certain specificities of their own.

\section{Credit system and school year}

This is the part where everybody agrees on. School year consists of 60 points, and in all countries except our, all the 60 points have to achieved in order to enroll the next school year on the budget. In some countries there are different exceptions to this rule. Students who work or pay the studies by themselves can enroll the next years with less number of points. The classes of subjects that remain unpassed have to be revisited. Points can also be transferred to other countries in accordance with previous agreement of those countries.

In Canada there is a credit system which is slightly different from the European one. In the USA, school year consists of 30 points, while in Russia credit system is still just underway.

\section{Assessment and examination terms}

It was expected the simplest and clearest answer to this question. However, it was not so. System of assessment differs from institution to institution, consisting of written part, oral examination part, etc. The number of terms is also different, from 1 to 3 , and they can start from immediately after finishing classes until next semester. Preexamination obligations nobody even mentions. So, everything differs with the institutions and teachers. Regardless of the definition of the system of examination, teachers in our country work differently. Nobody even mentions more than three examination terms.

On the other hand, system of assessment can also be a part of business strategy which manages the institution with the aim of achieving better business results.

\section{Enrollment of next year}

Basically, students on a budget should pass subjects which worth 60 points in order to enroll the next school year. But, there are also some more possibilities in other countries. There is no unanimous decision as for that; probably it is decided in accordance with the faculty and state policy. We have the impression that the number of budget students is higher than in our country, which could be explained by the fact that those countries are richer. Entrance fees are not fully in accordance with it, because they range from some sums that are symbolic even for us, to suggested sums in Great Britain that have recently cause student strikes.

\section{Work and independence of teachers}

Work of teachers is independent and they are autonomous in the teaching process. Working hours are not defined and the presence of students is not recorded. Performance is measured by load in teaching and additionally in research. Responsibility for the quality of their work and its providing is present in all the faculties, universities and schools. However, individual and collective consciousness is at such a level that all-day work is not brought into question, so this question was not initially fully understood by most people. 


\section{Issues in Information Systems}

Volume 14, Issue x, pp. 451-457, 2013

\section{PROGRAMMES OF STUDYING}

Studying programmes are not compared here, but in most institutions they are in accordance with the field they belong to. For example, in Serbia, on accreditation of studying programmes it is required that studying programmes are in accordance with contemporary world trends and state of the profession, science and art in adequate education-scientific, i.e artistic-education field, and comparable to similar programmes in foreign higher education institutions, especially within European education space.

Already mentioned cooperation of Higher Education Technical School of Professional Studies in Novi Sad with Russia beside the exchange of teachers as guest-lecturers is also present in the exchange of students of Fire Protection and Rescue. Our and Russian students passed certain elements of practical teaching of rescuing in both Serbia and Russia.

Several of our second-year students of IT successfully visited and passed some expert exams online at Macon State College. What initially appeared as the problem with higher education institutions of Russia and the USA is the presence of general subjects on the first two studying years with contents that are present at secondary level in most European countries, including Serbia. During the attempt of exam recognition, obtaining both degrees and creating joint programme, the absence of those subjects in us must be bridged somehow [9].

\section{CONCLUSION}

Regardless the mentioned differences that are significant in work, we hold the opinion that harmonization of the complete education system is possible. It is also possible the approaching of some related studying programmes. In that way, the space for horizontal and vertical mobility of students and teachers could be released [8]. The basic problem here is how to organize the agreement.

In order to make trustworthy opinions, it is necessary to test them via discussions of credible people which is not possible at one place and at one time.

We hope that by good will and mutual understanding it will be possible to achieve many agreements on cooperation and exchange, with the purpose that highly educated part of the population becomes more connected for common sake, progress and better mutual understanding. We are proud of the fact that our students had the possibility to also try other education systems and proved that they are successful, at the same time confirming the quality of our institution. That is our primary goal which should endeavor each higher school institution in the times when education should have no limits.

"In place of the monolithic, territorially defined referential community - the nation-state - that evolved over the past 190 years or more, the power both of a superordinate community and of subnational units is growing. A further drift in influence away from the nation-state is a possibility. Whatever the factors involved, however, they will not be rooted exclusively in Europe. Rather, they are likely to be shaped by Europe's adjustment to globalization."

$[10$, p.161)

\section{REFERENCES}

1. Akreditacija u visokom obrazovanju (Accreditation in higher education), (2010). Ministarstvo prosvete Republike Srbije (Ministry of Education of the Republic of Serbia), Belgrade http://www.kapk.org/index.php

2. Bernatik, A., (2010). Rules of studying - survey, Technical University, Ostrava, Czech Republic

3. Bideaux, E., (2010). Rules of studying - survey National Institute of Applied Sciences, Lyon, France

4. The Bologna Declaration of 19 June 1999 Retrieved May 9, 2013, from http://www.bolognaberlin2003.de/pdf/bologna declaration.pdf

5. Brodahl, C., Rules of studying - survey University in Agder, Norway

6. Cartelli, A., (2010). Rules of studying - survey University Monte Casino, Italy

7. Christozov, D., (2010). Rules of studying - survey American University, Bulgaria

8. London Communiqué Towards the European Higher Education Area: responding to challenges in a 
globalised world, (2007). Retrieved May 9, 2013, from http://europa.eu/legislation_summaries/education training_youth/lifelong_learning/c11088 en.htm

9. Koohang, A., (2012). Pros and Cons of International Collaboration: A Case of Serbia and the United States. Knowledge and Learning International Conference, Celje, Slovenia

10. Neave, G., 2003. The Bologna Declaration: Some of the Historic Dilemmas Posed by the Reconstruction of the Community in Europe's Systems of Higher Education. EDUCATIONAL POLICY, Vol. 17 No. 1, January and March 2003 pp.141-164.

11. Nikolic, B., \& Ruzic-Dimitrijevic, L. (2011). Упоредна анализа основних правила студија у Србији и неким земљама Европе и Америке (A comparative analysis of the basic study rules in Serbia and some countries of Europe and America.). XVII Skup Trendovi razvoja: Evropa 2020: društvo zasnovano na znanju, Serbia, pp. 114-118.

12. Perlin, A., (2010). Rules of studying - survey St.Petersburg University of State Fire Service, Russia

13. Report to the Ministers of Education of the signatory countries: Furthering the Bologna Process Prague, May 2001 Rapporteur: Pedro Lourtie Report commissioned by the Follow-up group of the Bologna Process

14. Ruzic-Dimitrijevic, L., \&.Nikolic, B., (2010) Bologna - sjajna zamisao, ali ... (Bologna - great idea, but...) XVI Skup Trendovi razvoja: Bologna 2010: stanje, dileme i perspektive" Kopaonik, Serbia

15. Ruzic-Dimitrijevic, L., \&.Nikolic, B., (2013) Elements of recognition of studying after bologna system. XIX Skup Trendovi razvoja: “UNIVERZITET NA TRŽIŠTU...” Maribor, Slovenia

16. Schleyer, G., (2010). Rules of studying - survey University of Liverpool, UK

17. Sedgwick, R., 2001. Implementation of the Bologna Declaration, Part II: Germany, 2001. March/April, Volume 14, Issue 2

18. Sedgwick, R., 2001. Implementation of the Bologna Declaration, Part III: Italy, Part IV: Austria, Maj/June 2001, Volume 14, Issue 3

19. Sedgwick, R., 2001. Implementation of the Bologna Declaration: The Netherlands and Greece , 2001. March/April, Volume 14, Issue 4

20. Travica, B., (2010). Rules of studying - survey University of Manitoba, Canada

21. Ziemba, E., (2010). Rules of studying - survey Economical University of Katowice, Poland

22. Zakon o visokom obrazovanju (Law on higher education), (2005). Službeni glasnik RS, (Official Gazette of Republic of Serbia) 76/2005, Belgrade, Serbia. www.uns.ac.rs/sr/zakon/zakon.htm 